Postmaster-General had taken over the film library, thereby saving it from dispersal. Now we learn that, through the generosity of a private individual in Scotland, it will be possible to continue the displays of Empire films in the cinema attached to the Imperial Institute Galleries. A full programme of films, lectures and talks on the British Empire has, therefore, been arranged for October and particulars of this may be obtained free on application to the Secretary, Imperial Institute, London, S.W.7.

\section{Magnetic Chart of the Ukraine}

WE learn from the Society for Cultural Relations (S.C.R.) that the expedition from the Odessa Geophysical Observatory, under the leadership of Prof. M. A. Aganin, has completed the survey work in the Ukraine, and a magnetic chart of the whole of the Ukrainian Soviet Republic will soon be available. The survey has established the fact that the so-called Kursk magnetic anomaly extends over territory far beyond Kursk, reaching Kharkov.

\section{Exploration of the Stratosphere}

The Russian experimenters at Moscow succeeded in launching their stratosphere balloon Stratostat U.S.S.R. on September 30, and ascended to a height of some 19,000 metres. The balloon landed safely at Kolomna, about seventy miles south-east of Moscow, after a flight of seven hours. The sealed gondola, made of duralumin, was manned by MM. Prokofieff, Birnbaum and Godunoff, the latter of whom made scientific observations. They were in touch with the Popoff wireless station in Moscow during the flight. A preliminary report from the Riga correspondent of the Times states that the minimum external temperature recorded was $-67^{\circ} \mathrm{C}$.

\section{Announcements}

THE Chemical Society has arranged a lecture, with experiments, by Prof. W. A. Bone on "The Com. bustion of Hydrocarbons", to be delivered at 8 p.m. on October 19 at the Royal Institution. Admission is free, without ticket.

Prof. E. A. Milne will deliver an address entitled "Some Points in the Philosophy of Physics: Time, Evolution and Creation", at University College, Gower Street, W.C.1, at 8.15 p.m., on Tuesday, October 17, under the auspices of the British Institute of Philosophy. Prof. E. N. da C. Andrade will be in the chair. Tickets can be obtained from the Director of Studies, at University Hall, 14 Gordon Square, W.C. 1 .

ON September 28, M. Lemoine established a new altitude record for an aeroplane in a flight at Villacoublay. It is stated in the Times that the official figure for the height reached is 13,661 metres.

FIFTY years ago, the late Sir Alexander Kennedy founded the Engineering Society of University College, London. The jubilee will be celebrated by a dinner to be held on November 16 at the College.
Old students of the Faculty of Engineering of the College proposing to be present should communicate with Prof. W. C. Clinton, University College, London, W.C.1.

LoRD IrwIn, president of the Board of Education, will make a presentation, on behalf of the Advisory Council of the Science Museum, on October 11 at 10.30 a.m., to Sir Henry Lyons, the retiring director of the Museum. An appreciative note, referring to Sir Henry's twenty-one years of service in the Science Museum, appeared in our issue of July 8, p. 55 .

Dr. A. Vedec TANING informs us that the collections of the Dana expedition, and also those of the Danish Commission for the Exploration of the Sea referring to the Faeroe Isles and Iceland, hitherto housed in the late Prof. Johs. Schmidt's department at the Carlsberg Laboratory, have been transferred to the Marinbiologisk Laboratorium, Vestre Boulevard 42, Copenhagen, $\mathrm{v}$.

Applicatrons are invited for the following appointments, on or before the dates mentioned:- Six inspectors of factories (Class II)--Industrial Division, Home Office, London, S.W.1 (Oct. 9). A temporary mechanical engineering draughtsman, Air Ministry, and a temporary assistant in the Designs Branch of the Directorate of Works and Buildings, Air Ministry-Secretary (S. 2), Air Ministry, Adastral House, Kingsway, W.C.2 (Oct. 10). A principal of Londonderry Municipal Technical School-Secretary and Executive Officer, Education Office, Guildhall, Londonderry (Oct. 13). Assistant civil engineers, Air Ministry-Secretary (S. 2), Air Ministry, Adastral House, Kingsway, W.C.2 (Oct. 14). A lecturer in the department of mechanical and civil engineering, Sunderland Technical College-Chief Education Officer, Education Offices, 15 John Street (Oct. 16). A lecturer in horticulture in the Iepartment of Agriculture of the University of Leeds-Registrar (Oct. 23). A visiting teacher for refrigeration engineering at the School of Engineering and Navigation, Poplar, E.14-Education Officer (T. 1), County Hall, S.E.1, with stamped addressed foolscap envelope (Oct. 26). Probationary inspectors (male) in the engineering department of the Post Office-Secretary, Civil Service Commission, Burlington Gardens, London, W.1 (Oct. 26). A research fellow for investigations in the University of Leeds in association with the Harrogate Royal Baths Hospital, into the cause and care of chronic rheumatism-Registrar, University, Leeds (Oct. 28). An assistant librarian in the Nottingham County Library-Director of Education, Shire Hall, Nottingham (Oct. 31). A head of the Department of Sanitary Engineering and Plumbing in the Victoria Jubilee Technical Institute, Matunga, Bombay-The Engineer Office, 28 Essex Street, W.C.2.

Erratum.-Dr. C. J. Gorter writes pointing out that formula (3) in his letter "Remanence in Single Crystals of Iron" (NATURE, Sept. 30, p. 517) was incorrectly written in his manuseript as $F_{d}=2 \pi I_{p}^{2}$. It should be $F_{d}=\pi I_{p}^{2}$. 